\title{
제 3차 포스트 부산 임시그룹(PBIG) 회의
}

\section{I . 회의개요}

제 3차 포스트 부산 임시그룹(Post Busan Interim Group) 회의가 2012년 5월 21일부터 22 일까지 파리 $\mathrm{OECD}$ 본부에서 개최 되었다.

\section{II . 주요내용}

- 부산총회 결과문서에서 6 월까지 합의키로 한 글로벌 파트너십 세부 운영방안 및 글로벌 모 니터링 체제에 대해 마지막 협의가 이루어짐.

- 금번 회의에서 합의된 내용을 반영한 최종 제안서는 6.28-29 원조효과작업반에 상정, 승인키로 하고, 합의되지 않은 사항에 대해서는 추후 글로벌 파트너십에서 협의

- (글로벌 파트너십 거버넌스) 글로벌 파트너십의 실질적인 운영을 담당할 집행위원회의 규 모는 총 18명으로 제안키로 함.

- 집행위원회에 참여하는 개발주체는 기존에 합의된 안을 유지하되, 공여국과 수원국 대 표는 각각 2 명을 추가(공여국 4 , 수원국 6 )

- 공동의장은 장관급으로, 여타 집행위원회 멤버는 고위급으로 구성

- 6.10일까지 공동의장 및 여타 집행위원회 후보자 선정 추진

- (글로벌 모니터링 체제) 지난 제2차 PBIG회의에서 합의한 7 개 분야를 모니터링할 10 개 지 표에 대해 합의함.

- 합의된 지표들의 세부 정의, 측정방법, 목표치에 대해서는 기술적인 검토를 거쳐 최종안 을 6 월 원조효과작업반 이전에 회람

- (남남협력국의 글로벌 모니터링 참여방안) 한국 제안으로 부산 파트너십 정신을 살린 남남 협력국의 자발적인 글로벌 모니터링 참여 원칙과 진화하는 프로세스를 강조한 조항이 새롭 게 추가됨.

\section{III. 관찰 및 평가/건의}

- 우리나라를 비롯 DAC 국가들의 주장으로 글로벌 파트너십 집행위원회에 배정된 공여국 자리가 2 에서 4 개(공동 의장 포함)로 증가하였으나, DAC내 북구, $\mathrm{EU}$, 미국, $\mathrm{CANZ}$ 국가 
등에서 참여를 위한 경쟁이 치열할 것으로 전망됨. 이에 따라, 우리나라도 새롭게 출범하 는 글로벌 파트너십 집행위에 부산총회 주최국으로 참여하는 것이 긴요할 것으로 보이며, 이를 위해 $\mathrm{DAC}$ 회원국과 $\mathrm{DAC}$ 의장에게 적극적 참여 의지를 조기에 표명하는 것이 필요 할 것으로 사료됨.

- 공여국들은 6.1 일 전화회의를 통해 공여국 대표 선정 문제를 논의할 예정

- 우리측이 제안한 남남협력국의 글로벌 모니터링 참여 방안 문안이 주요 신흥국들의 지지를 얻어 포함됨으로써 남남협력국의 부산 파트너십 참여 검토에 긍정적으로 기여할 것으로 기 대됨.

- 금번 회의에서 인도, 브라질 등은 글로벌 파트너십 참여에 긍정적 입장을 표명하였으나, 중국은 이번 회의에 참석하지 않았음. 특히, 중국의 참여가 긴요한 만큼, 중국과 양자 접 촉 등을 통해 참여를 권유하는 것이 필요할 것으로 보임.

- 6 월 새롭게 출범하는 글로벌 개발 파트너십 및 모니터링에 대비해 우리 ODA 체제를 새로 운 개발 규범에 부합하도록 내재화하는 범정부적 작업이 필요할 것으로 사료됨. 